\title{
Impact Of Covid-19 on Financing Islamic Bank in Indonesia
}

\author{
Dhaffi Rizwan Azhari', Muhammad Iqbal Fasa'2, Dedi Junaedi ${ }^{3}$, M Rizal Arsyad ${ }^{4}$ \\ 1.2Universitas Islam Negeri Raden Intan Lampung \\ 3IAI Nasional Laa Roiba Bogor \\ ${ }^{4}$ Universitas Gunadarma \\ dhaffi.r.azhari@gmail.com¹, miqbalfasa@radenintan,ac.id² \\ dedijunaedi@laaroiba.ac.id³, mr.arsyad@staff.gunadarma.ac.id4
}

\begin{abstract}
Financing is the largest source of income for Islamic banks, but at the same time it is the largest source of business operating risk. Regarding the impact of the Covid-19 pandemic on financing at Islamic banks, it is not only reducing the income of Islamic banks, but also the economic sector of a country. This study aims to analyze the impact of Covid-19 on financing in Sharia banks, not only lowering the level of income of Sharia banks, but also referring to the decrease in the level of the economy of a country. This study aims to analyze the impact of Covid-19 on financing in Sharia banks. The method used in this study is qualitative research method with case study design. Case study method is a unit-level learning design of education this method takes the form of an explanation of a particular problem, event or situation, then students are tasked with finding alternative solutions then this method can also be used to develop critical thinking and find new solutions to a topic that is solved. Independent variables impact covid-19. Dependent variables of sharia bank financing
\end{abstract}

\section{Keywords: COVID-19, Islamic Banking, Financing}

\begin{abstract}
ABSTRAK
Pembiayaan adalah sumber pendapatan bank syariah yang terbesar, namun sekaligus merupakan sumber risiko operasi bisnis yang terbesar. Dampak pandemi Covid-19 terhadap pembiayaan di bank syariah bukan hanya menurunkan pendapatan bank syariah, melainkan sektor perekonomian suatu negara. Penelitian ini bertujuan untuk menganalisis dampak Covid-19 terhadap pembiayaan di bank syariah. Metode yang digunakan dalam penelitian ini metode penelitian kualitatif dengan desain studi kasus, yaitu suatu desain pembelajaran berbasis tingkat satuan pendidikan. Metode ini berbentuk penjelasan tentang masalah, kejadian atau situasi tertentu, kemudian mahasiswa ditugasi mencari alternatif pemecahannya. Metode ini dapat juga digunakan untuk mengembangkan berpikir kritis dan menemukan solusi baru dari suatu topik yang dipecahkan. Variabel independennya dampak Covid-19. Variabel dependennya pembiayaan bank syariah.
\end{abstract}

Kata kunci: COVID-19, Perbankan Syariah, Pembiayaan 


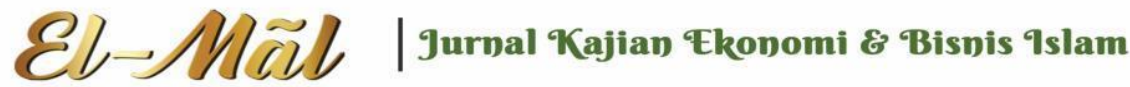

\section{Vol 3 No 2 (2020) 144-155 P-ISSN 2620-295 E-ISSN 2747-0490 DOI: 1047467/elmal.v3i1.507}

\section{PENDAHULUAN}

Sudah 1 tahun lebih dunia mengalami fenomena virus yang sangat luar biasa, yaitu Acute Respiratory Syndrome Coronavirus 2 (Sars-CoV-2), yang merupakan penyakit menular yang menyebabkan penyakit di bagian paru-paru seperti infeksi paru-paru (pneumonia), Middle-East Respiratory Syndrome (MERS), dan Severe Acute Respiratory Syndrome (SARS). Virus ini menular dengan cepat dan telah menyebar ke wilayah lain di Cina dan ke beberapa negara, termasuk Indonesia. Hal ini membuat negara-negara menerapkan kebijakan memberlakukan lockdown dalam rangka mencegah penyebaran virus Corona. Kasus Covid-19 ditemukan pertama kali di Tiongkok pada November 2019. Covid-19 merupakan penyakit karena infeksi virus yang penyebarannya sangat cepat. Wabah Covid-19 memberikan dampak ke seluruh sektor kehidupan, tak terkecuali juga berdampak pada sistem perbankan. Hal ini menyebabkan sistem keuangan tergerus dan terperosot, termasuk sistem bunga yang ada pada bank konvensional. Sebagaimana instruksi Gubernur Bank Indonesia (BI), perbankan diharapkan segera menurunkan bunga kredit (Laucereno, 2020). Selain sektor perekonomian, dampak yang dirasakan sekarang ialah, sekolah di rumah, kerja di rumah (work from home), belum lagi diterapkannya social distancing hingga physical distancing, yang pasti akan mempengaruhi keadaan ekonomi Indonesia. Saat sesorang kerja dari rumah, sekolah dari rumah pasti akan membawa dampak perekonomian, seperti berpengaruhnya ojek online, jasa angkutan umum, armada bus, hingga penerbangan sekali pun.

Tabel 1.

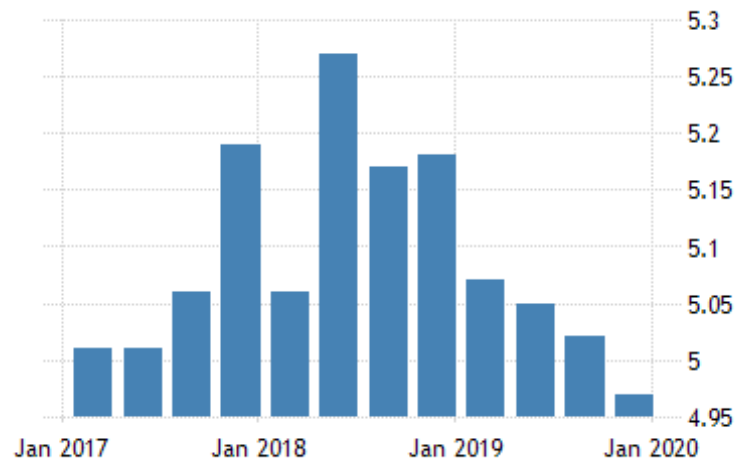

sumber: Pertumbuhan PDB (y-on-y) 2020

Dari gambaran tabel tersebut dapat dilihat bahwa pertumbuhan ekonomi tahunan Indonesia sedikit menurun menjadi 4,97 persen pada kuartal keempat 2019 dari 5,02 persen pada periode tiga bulan sebelumnya, sedikit di bawah konsensus pasar 5,04 persen. Itu adalah laju ekspansi terlemah sejak kuartal keempat 2016, karena kenaikan konsumsi rumah tangga yang lebih lemah (4,97 persen vs 5,01 persen pada Q3), investasi tetap (4,06 persen vs 4,21 persen) dan pengeluaran pemerintah $(0,48$ persen vs 0,98 persen). Selain itu, ekspor turun 0,39 persen (vs 0,10 persen pada Q3) dan impor 


\section{| Jurnal Kajian Ekonomi \& Bisnis Islam}

\section{Vol 3 No 2 (2020) 144-155 P-ISSN 2620-295 E-ISSN 2747-0490 DOI: 1047467/elmal.v3i1.507}

turun lebih cepat 8,05 persen (vs $-8,30$ persen). Di sisi produksi, pertumbuhan output melambat terutama untuk manufaktur, pertambangan, perdagangan eceran dan grosir, kegiatan real estat, pendidikan dan layanan sosial. Untuk 2019, ekonomi tumbuh 5,02 persen, di bawah ekspektasi pasar 5,03 persen dan target pemerintah 5,3 persen. Itu adalah pertumbuhan tahunan terlemah sejak 2015. Bank Indonesia memperkirakan tingkat pertumbuhan PDB sebesar 5,3 persen di tahun 2020 (Otoritas Jasa Keuangan, 2020).

Respons pemerintah sebagai upaya mengatasi krisis keuangan pada kondisi pandemi dilakukan dengan mengeluarkan regulasi atas pengaturan keuangan negara. Ada dua regulasi keuangan negara yang dikeluarkan pemerintah untuk mengatur pembiayaan keuangan bagi masyarakat. Dua aturan tersebut yaitu Peraturan Pemerintah Pengganti Undang-Undang (Perpu) Nomor 1 Tahun 2020 dan Peraturan Otoritas Jasa Keuangan (POJK) Nomor 11/POJK/03/2020. Kedua aturan tersebut menjadi payung hukum pemberlakuan restrukturisasi kredit atau pembiayaan bagi debitur yang terdampak pandemi Covid-19.

Berbagai kebijakan yang dikeluarkan untuk meringankan beban rakyat termasuk pemberian subsidi listrik dan bantuan tunai setiap bulan. Ini membuat anggaran negara terus menerus berkurang sementara tidak ada pemasukan yang membuat negara melakukan utang dalam jumlah besar, termasuk meluncurkan global kupon bon guna menstabilkan keadaan perekonomian di Indonesia (Syukra, 2020). Setelah virus ini merajalela dan berdampak pada semuanya, juga mempengaruhi pemerintah, maka pemerintah menyepakati melakukan tindakan refokusing dan realokasi anggaran belanja untuk penanganan pandemi dengan melakukan penghematan belanja. Penyesuaian alokasi Dana Bagi Hasil (DBH), Dana Alokasi Umum (DAU), dan Dana Insentif Daerah (DAD) dengan harapan kepala daerah dapat mengoptimalkan langkah tersebut untuk pencegahan Covid-19, sehingga akan terjadi penghematan sebesar Rp190 triliun dan termasuk realokasi cadangan sebesar Rp54,6 triliun (Statistik Perbankan Syariah, 2020). Selain itu, pemerintah juga meluncurkan kebijakan non-fiskal. Penyederhanaan larangan terbatas ekspor dan impor, serta percepatan layanan ekspor-impor melalui National Logistic Ecosystem (NLE) diterapkan demi menjaga ketersediaan barang yang dibutuhkan.

Covid-19 berdampak signifikan terhadap perkembangan ekonomi dunia. Pandemi telah membuat tantangan bagi dunia bisnis, termasuk industri jasa keuangan perbankan. Berdasarkan data statistik perbankan syariah pada Januari 2020, jumlah jaringan kantor Bank Umum Syariah adalah 1.922 cabang yang tersebar di berbagai wilayah di Indonesia yang didominasi pulau Jawa. Sejalan dengan wilayah terbanyak ditemukan Covid-19 yaitu di Pulau Jawa (Statistik Perbankan Syariah, 2020). Ini menunjukkan bahwa sebagian besar Kantor Bank Syariah berada di zona merah. Demikian pula penelitian yang dilakukan oleh McAleer, (2020), yang menyatakan kemampuan keamanan kesehatan global di 195 Negara GHS, mencantumkan negara-negara yang paling siap menghadapi epidemi atau pandemi. Walau pun negara-negara berpenghasilan tinggi melaporkan skor rata-rata 51,9, indeks menunjukkan bahwa secara kolektif, kesiapan internasional untuk epidemi dan pandemi masih sangat lemah. BI juga menurunkan Giro Wajib Minimum (GWM) Valas untuk bank umum konvensional dari semula 8 persen menjadi 4 persen, meningkatkan triple intervention di pasar spot, DNDF, melakukan pembelian SBN di pasar sekunder, menguatkan 


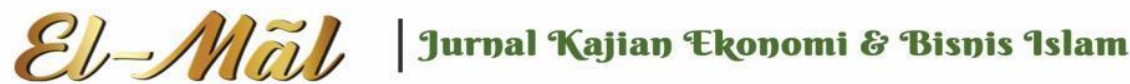

\section{Vol 3 No 2 (2020) 144-155 P-ISSN 2620-295 E-ISSN 2747-0490 DOI: 1047467/elmal.v3i1.507}

likuiditas rupiah dengan memperpanjang tenor repo SBN dan lelang tiap hari, memperluas underlying transaksi bagi investor asing, dan menggunakan bank kustodi global dan domestik untuk kegiatan investasi. Begitu juga dengan Otoritas Jasa Keuangan (OJK) yang memberikan stimulus untuk debitur melalui penilaian kualitas kredit hingga Rp10 Milliar berdasarkan ketepatan membayar. Berdasarkan pendahuluan tersebut maka peneliti mengambil judul penelitian terkait "Implikasi Dampak Covid-19 Acute Respiratory Syndrome Coronavirus2 (Sars-CoV-2) ON FINANCING in a SHARIAH BANK"

\section{TINJAUAN PUSTAKA}

\section{Bank Syariah}

Bank merupakan entitas yang melakukan penghimpunan dana dari masyarakat dalam bentuk pembiayaan, melaksanakan fungsi intermediasi keuangan. Menurut UU No.21 Tahun 2008 tentang Perbankan Syariah, bank syariah merupakan bank yang menjalankan kegiatan usaha yang berprinsip syariah, yang berdasarkan fatwa MUI. Seperti prinsip keadilan dan keseimbangan ('adl wa tawazun), kemaslahatan (maslahah), universalisme (alamiyah), serta tidak mengandung gharar, maysir, riba, zalim, dan lain-lain. Secara umum bentuk usaha bank syariah terdiri atas Bank Umum dan Bank Pembiayaan Rakyat Syariah (BPRS), dengan perbedaan pokok BPRS dilarang menerima simpanan berupa Giro dan ikut serta dalam lalu lintas sistem pembayaran. Secara kelembagaan terdapat bank umum syariah penuh (full-pledged), dan terdapat pula bentuk Unit Usaha Syariah (UUS) dari bank umum konvensional (Otoritas Jasa Keuangan, 2017).

Perbankan syariah semakin berkembang setelah dikeluarkan Undang-Undang No. 7 tahun 1992 tentang Perbankan, yang secara eksplisit memperbolehkan bank menjalankan usahanya berdasarkan prinsip bagi hasil. Hal tersebut dipertegas dengan dikeluarkannya Peraturan Pemerintah (PP) No. 72 tahun 1992 tentang Bank Berdasarkan Prinsip Bagi Hasil. Dalam rangka menghindari pembayaran dan penerimaan riba atau bunga, maka dalam melaksanakan kegiatan pembiayaan (financing), perbankan syariah menempuh mekanisme bagi hasil (profit and loss sharing investment) sebgai pemenuhan kebutuhan permodalan (equity financing) dan investasi berdasarkan imbalan (fee based investment) melalui mekanisme jual beli sebagai pemenuhan kebutuhan pembiayaan (debt financing) (Arifin, 2002).

Pendapatan bank syariah sendiri tidak diperoleh dari bunga, melainkan dari :

1. Biaya administrasi terhadap penyaluran kredit al-qardh

2. Mark up terhadap penyaluran kredit-kredit al-murabahah dan al-ba'bi saman'ajil

3. Bagi hasil dari penyaluran kredit-kredit al-mudharabah dan al-musarakah 


\section{| Jurnal Kajian Ekonomi \& Bisnis Islam}

\section{Vol 3 No 2 (2020) 144-155 P-ISSN 2620-295 E-ISSN 2747-0490 DOI: 1047467/elmal.v3i1.507}

4. Fee terhadap penggunaan jasa-jasa perbankan umumnya seperti al-kafalah (jaminan bank), al-hiwalah (pengalihan utang), al-jialah (pelayanan khusus), al-wakalah (penerbitan letter of credit) dan sebagainya.

Dana pihak bank syariah tidak memperoleh imbalan bunga simpanan tetapi memperoleh imbalan bagi hasil dari pendapatan bank sesuai dengan porsi dan perannya pada pembentukan pendapatan bank tersebut (Perwataatmadja, 1992).

\section{Faktor-faktor yang Mempengaruhi Pembiayaan}

Secara umum pembiayaan merupakan salah satu tugas pokok bank, yaitu pemberian fasilitas penyediaan dana untuk memenuhi kebutuhan pihak-pihak yang merupakan defisit unit. Bank Syariah suatu lembaga keuangan yang usaha pokoknya memberikan kredit dan jasa-jasa dalam lalu lintas pembayaran serta peredaran uang yang pengoperasiannya disesuaikan dengan prinsip-prinsip syariah Islam (Ensiklopedia Bank Syariah, n.d.).

Bank syariah dapat membantu memenuhi kebutuhan modal kerja tersebut bukan dengan meminjamkan uang, melainkan dengan menjalani hubungan partnership dengan nasabah, di mana bank bertindak sebagai penyandang dana (shahibul maal), sedangkan nasabah sebagai pengusaha (mudharib). Skema pembiayaan semacam ini disebut dengan mudharabah (trust financing). Dalam hal ini bank syariah mempunyai dua peran utama yaitu sebagai badan usaha (tamwil) dan badan sosial (maal). Sebagai badan usaha, bank syariah mempunyai beberapa fungsi yaitu sebagai manajer investasi, investor dan jasa pelayanan. Bank syariah sebagai manajer investasi melakukan penghimpunan dana dari para investor/nasabah dengan prinsip wadiah yad dhamanah (titipan), mudharabah (bagi hasil) atau ijarah (sewa). Sebagai investor, bank syariah melakukan penyaluran dana melalui kegiatan investasi dengan prinsip bagi hasil, jual beli dan sewa. Sebagai penyedia jasa perbankan, bank syariah menyediakan jasa keuangan, jasa non keuangan dan jasa keagenan. Pelayanan jasa keuangan antara lain dilakukan dengan prinsip wakalah (pemberian mandat), kafalah (bank garansi), hiwalah (pengalihan hutang), rahn (jaminan utang/gadai), qardh (pinjaman kebajikan untuk dana talangan ), sharf (jual beli valuta asing) dan lain-lain (Amirillah, 2014).

Pelayanan jasa nonkeuangan dalam bentuk wadiah yad amanah (safe deposit box) dan pelayanan jasa keagenan dengan prinsip mudharabah muqayyadah. Faktor-faktor input dan output yang digunakan dalam mengukur efisiensi pembiayaan pada bank syariah seperti dijelaskan oleh Karsinah \& Cahya (2014) merupakan total simpanan, aset tetap, dan beban operasional sebagai faktor input serta pendapatan yang didapatkan dari pembiayaan dan laba operasional sebagai variabel output. Salah satu faktor yang diprediksi mempengaruhi pembiayaan bermasalah adalah ukuran bank. Pada perbankan ukuran lebih cenderung dilihat dari total asetnya mengingat produk utamanya adalah pembiayaan serta investasi. Bank dengan aset yang besar memiliki kemungkinan untuk menghasilkan keuntungan yang lebih besar apabila diikuti dengan hasil dan aktivitasnya. Menurut Misra \& Dhal, (2010) bank-bank besar lebih cenderung memiliki tingkatan kredit macet lebih tinggi karena kendala neraca. Bank-bank kecil bisa menunjukkan efisiensi manajerial lebih baik 


\section{Vol 3 No 2 (2020) 144-155 P-ISSN 2620-295 E-ISSN 2747-0490 DOI: $1047467 /$ elmal.v3i1.507}

daripada bank-bank besar dalam hal penyaringan pinjaman dan pemantauan pasca pinjaman, yang menyebabkan tingkat kegagalan lebih rendah.

Warjiyo (2004) menyatakan bahwa pertumbuhan kredit dipengaruhi oleh penawaran kredit perbankan. Penawaran dipengaruhi oleh dana yang tersedia yang bersumber dari DPK, persepsi bank dari usaha debitur, dan kondisi perbankan itu sendiri seperti permodalan atau CAR (Capital Adequacy Ratio), jumlah kredit macet atau NPL (Non Performing Loan), dan LDR (Loan to Deposit Ratio). Dengan terjadinya dampak wabah Covid-19 terdapat 6 bank yang memberlakukan kebijakan relaksasi, yaitu Bank BJB, dan Bank BPD Bali, Bank BPD NTT, Bank Sumut, Bank Sumsel Babel, dan Bank Jateng.

\section{Covid-19 (Acute Respitory Syindrome Coronavirus 2 (Sars-CoV-2))}

WHO (World Health Organization) merupakan organisasi kesehatan yang memberikan penjelasan mengenai Coronaviruses (Cov), yang menginfeksi sistem pernapasan pada manusia. Covid-19 pertama kali ditemukan di Wuhan, Cina pada tanggal 30 Desember 2019, di mana Wuhan Municipal Health Committee mengeluarkan penyataan "urgent notice on the treatment of pneumonia of unknown cause" (Sumarni, 2020).

Ada 7 jenis coronavirus yang dikenal dapat menginfeksi manusia, yaitu:

- Human coronavirus yang terdiri dari 229E (alpha coronavirus), NL63 (alpha coronavirus), 0C43 (betha coronavirus), dan HKU1 (betha coronavirus).

- MERS-CoV yang menyebabkan penyakit MERS (Middle East Respiratory Syndrome).

- SARS-CoV yang menyebabkan penyakit SARS (Severe Acute Respiratory Syndrome).

- $\quad$ SARS-CoV-2 yang menyebabkan penyakit Covid-19.

Covid-19 membuat Cina menjadi negara darurat kesehatan masyarakat dan menimbulkan risiko tinggi bagi negara-negara dengan sistem kesehatan yang sangat rentan. Covid-19 memiliki sifat yang menyebar (menular) dari satu orang ke orang lainnya, penularannya sangat cepat lintas negara, dan sudah menyebar ke seluruh dunia. Pandemi Covid-19 berdampak luas baik dari segi ekonomi, politik, sosial, dan dampak yang signifikan adalah pemerosotan segi ekonomi.

\section{METODE PENELITIAN}

Metode penyelesaian penelitian ini menggunakan metode penelitian kualitatif dengan desain studi kasus. Metode studi kasus merupakan suatu pembelajaran berbasis tingkat satuan pendidikan metode yang bebentuk penjelasan terkait masalah, kejadian atau situasi tertentu, kemudian mahasiswa ditugaskan mencari alternatif pemecahannya. Metode ini dapat juga digunakan uuntuk mengembangkan berpikir kritis dan menemukan solusi baru dari suatu topik yang dipecahkan (Yamin, 2007). Kemudian ditambahkan dengan objek kajian empiris yang menguat gambaran suatu relaksasi Bank Syariah dalam penundaan pembayaran angsuran atau pemberian keringanan 


\section{Vol 3 No 2 (2020) 144-155 P-ISSN 2620-295 E-ISSN 2747-0490 DOI: $1047467 /$ elmal.v3i1.507}

pembayaran sewa atau margin dengan kurun waktu dan syarat-syarat yang disesuaikan dengan sektor ekonomi, kriteria, dan kondisi nasabah. Variabel independennya dampak Covid-19. Variabel dependennya pembiayaaan Bank Syariah.

\section{HASIL \& PEMBAHASAN}

Perbankan syariah tengah mencermati perkembangan dari dampak pandemi Covid-19 terhadap pembiayaan. Optimisme bank di awal tahun dengan memasang target pembiayaan cukup tinggi perlahan meredup karena pandemi Covid-19 telah memukul berbagai sektor ekonomi. Untuk meminimalkan dampak Covid-19, termasuk di sektor industri perbankan pemerintah melalui OJK mengeluarkan kebijakan stimulus perekonomian nasional sebagai kebijakan Countercylical Dampak Penyebaran Coronavirus Disease 2019 (Covid-19), dengan menerbitkan POJK No. 11/POJK.03/2020. Kebijakan stimulus yang dimaksud terdiri atas kebijakan penilaian kualitas pelayanan hanya didasarkan pada ketetapan pembayaran pokok dan margin/bagi hasil/ujrah dengan pembiayaan yang mencapai 10 miliar dan skema restrukturisasi pembiayaan (Otoritas Jasa Keuangan, 2020b).

Sebelum merger 3 bank syariah disahkan menjadi Bank Syariah Indonesia (BSI), sejumlah bank syariah mengalami pemangkasan besar terkait target pembiayaan tahun 2020 menjadi lebih konservatif. Contoh studi kasus sebelum perubahan merger kasus pada PT. Bank BNI Syariah, yang sebelumnya memasang target pembiayaan tumbuh 15\%-17\%, namun, penyebaran Covid-19 yang telah memukul aktivitas ekonomi membuat bank ini lebih berhati-hati dalam mengelola portofolio pembiayaan eksisting dan melakukan ekspansi. BNI Syariah juga hanya tumbuh 9,69\%, padahal periode yang sama tahun sebelumnya masih tumbuh dua digit. Sejauh ini dampak pandemi Covid-19 terhadap kualitas aset bank ini memang belum terasa, secara umum dampak virus corona memang membuat permintaan kredit melambat. Tetapi menurut Hutauruk (2020), tidak semua sektor terpuruk. Untuk NPF tidak berdampak, masih terjaga di level 0,6\% (Hutauruk, 2020).

Wabah Coronavirus 2019 (Covid-19), yang pertama kali dilaporkan pada Desember 2019 di Wuhan, Cina, dan telah dinyatakan sebagai darurat kesehatan publik yang menjadi perhatian internasional oleh Organisasi Kesehatan Dunia, dapat berkembang menjadi pandemi yang terkait dengan mobilitas dan mortalitas yang substansial (Thariq \& Goniewicz, 2020). Penyebaran Covid19 ke Indonesia, membuat pemerintah melakukan pembatasan sosial untuk mencegah penyebaran lebih luas. Pembahasan dalam tulisan ini memfokuskan sudut pandang pembiayaan di bank syariah. Kemudian secara perlahan sektor perbankan syariah mulai menemukan titik untuk menguat lagi sektor perbankan syariah agar naik. 


\section{Vol 3 No 2 (2020) 144-155 P-ISSN 2620-295 E-ISSN 2747-0490 DOI: 1047467/elmal.v3i1.507}

\begin{tabular}{|c|c|c|c|c|c|c|c|}
\hline & \multicolumn{2}{|c|}{ BNI Syariah } & \multicolumn{2}{|c|}{ BRI Syariah } & \multicolumn{2}{|c|}{ Mandiri Syariah } & \multirow{2}{*}{\begin{tabular}{|c|} 
Bank Syariah \\
Indonesia \\
Per Desember \\
2020 \\
\end{tabular}} \\
\hline & 2019 & 2020 & 2019 & 2020 & 2019 & 2020 & \\
\hline Total Aset & 44,98 & 55,01 & 43,12 & 57,70 & 112,29 & 126,85 & 239,56 \\
\hline Pembiayaan & 43,77 & 47,97 & 34,12 & 49,34 & 99,81 & 112,58 & 209,98 \\
\hline Dana Pihak Ketiga & 32,58 & 33,05 & 27,38 & 40,00 & 75,54 & 83,43 & 156,51 \\
\hline Laba & 0,6 & 0,5 & 0,074 & 0,25 & 1,28 & 1,43 & 2,19 \\
\hline
\end{tabular}

Tercatat per Desember 2020 aset BSI sudah mencapai Rp239,56 Triliun. Aset sebesar itu menempatkan BSI sebagai bank terbesar ke-7 di Indonesia dari sisi asetnya. Aset yang berkode saham BRIS yang berada di bawah PT Bank CIMB Niaga Tbk (Rp281,7 T.) dan di atas PT Bank Panin Tbk (Rp216,59 T) per September 2020. Aset yang sangat besar ini dapat mengungkit kemampuan lebih besar dalam mendukung pembiayaan 20 ekonomi. Di samping itu juga diharapkan dapat menjadi akselerator bagi pengimbangan ekonomi syariah di Indonesia (Alhusain, 2021).

Kegiatan digitalisasi UMKM syariah menjadi salah satu alternatif pemulihan perekonomian Indonesia di tengah pandemi Covid-19. Hasil penelitian Arifqi dan Junaedi (2021)menunjukkan bahwa digitalisasi UMKM syariah merupakan salah satu upaya untuk meningkatkan perekonomian Indonesia di masa pandemi Covid-19. Digitalisasi UMKM syariah memiliki peluang dan tantangan. Peluang kegiatan tersebut akan lebih mudah diterapkan, baik dalam produksi, distribusi maupun konsumsi. Tantangan yang dihadapi adalah minimnya sumber daya manusia dalam mengakses teknologi.

\section{KESIMPULAN}

Pandemi Covid-19 secara langsung maupun tidak langsung telah mempengaruhi sektor pembiayaan Bank Syariah. Bahkan bukan hanya di sektor pembiayaan bank syariah, Covid-19 telah memberikan dampak yang sangat signifikan terhadap penurunan ekonomi global, sector industry, pariwisata, biro perjalanan, dana salah satunya ialah sector perbankan terkhusus perbankan syariah. Dampak Covid-19 yang awalnya juga membuat sejumlah bank memangkas target pembiayaan menjadi lebih konservatif, salah satunya pada kasus PT. Bank BNI Syariah memasang target pembiayaaan $15 \%$ hingga $17 \%$ di tahun 2020.

Secara tidak langsung pengaruh Covid-19 membuat permintaan pembiayaan, aset dan lainlain melambat bahkan dapat menurun dengan signifikan.Tetapi secara bertahap sektor perbankan syariah dengan memaksimalkan stimulus dari perbankan sendiri dan sekarang telah merubah merger, di mana Bank Syariah Indonesia tidak mengalami pemerosotan dalam hal laporan keuangannya, baik pembiayaan maupun aset dan lain-lain. Berdasarkan OJK, sepanjang 2020. Pembiayaan bank syariah tumbuh hampir double digit, yakni 9,5\% dibanding tahun sebelumnya (Year-On-Year). Estimasi kinerja pembiayaan hingga kuartal III/2020 mencapai Rp40,3 triliun, tumbuh sebesar 57,9\% dibandingkan dengan periode yang sama pada tahun sebelumnya. 


\section{Vol 3 No 2 (2020) 144-155 P-ISSN 2620-295 E-ISSN 2747-0490 DOI: 1047467/elmal.v3i1.507}

Hasil penelitian Alfira et al (2021)menunjukkan bahwa dampak pandemi Covid-19 tidak hanya berdampak pada kesehatan masyarakat, namun juga berdampak pada perekonomian Indonesia khususnya pada lembaga keuangan syariah di pasar modal syariah yaitu IHSG dan melemahnya nilai tukar rupiah. kecepatan. Pandemi juga terbukti memberikan tekanan pada perekonomian dunia, termasuk Indonesia.

Data dan fakta penelitian menunjukkan pandemi COVID-19 telah menimbaulkan dampak multi sector. Bagi perekonomia, pandemic ini telah ikut memperparah efek kontraksi perekonomian bagi negara-negara di kawasan Asia, Amerika, Afrika, Eropa dan Asutralia/Oceania. Variabel kasus pandemic, waktu paparan, jumlah penduduk, perbedaan kawasan dan perbedaan status negara dapat menjelaskan dinamika pertumbuhan ekonomi negara terdampak sebesar $63,73 \%$, sisanya 26,27\% dipengaruhi oleh variabel lain yang tidak diteliti (Junaedi \& Salistia, 2020).

Jika pandemic terkendali (dalam kasus dan waktu paparan) serta tidak ada disparitas tatakelola antara kawasan dan antar status negara, maka pertumbuhan ekonomi global berpotensi positif $0.18 \%$. Jika belanja pemerintah untuk mengatasi pandemi dinaikan sebesar satu juta dolar, maka Langkah ini berpotensi mengurangi dampak kontraksi sebesar 0,027\% (Junaedi \& Salistia, 2021)

Tatakelola dampak pandemic di kawasan Asia, Amerika dan Afrika berbeda signifikans dengan tatakelola di negara kawasan Australia/Oceania. Sementara tatakelola pandemi di Eropa tidak berbeda signifikans dengan tatakelola negara Australia/Oceania. Perbedaan status negara maju berbeda nyata dengan negara miskisn. Tetapi, status negara menengah dengan negara miskin tidak berbeda nyata dengan tatakelola negara miskin. Secara relatif, dampak pandemi terhadap pertumbuahn ekonomi di kawasan Asia lebih berat dibanding kawasan lainnya. Urutan dampak pendemi terhadap pertumbuhan ekonomi kawasan berturut-turut dari yang terbeerat ke yang teringan adalah: Asia, Amerika, Afrika, Eropa dan Australia/Oceania. Urutan dampak pendemi terhadap pertumbuhan ekonomi kawasan dari yang terberat ke yang teringan adalah: Asia, Amerika, Afrika, Eropa dan Australia/Oceania (Junaedi \& Salistia, 2021).

Penelitian lain menunjukkan, jumlah kasus pandemi dan perbedaan kebijakan berpengaruh signifikan terhadap stabilitas nilai tukar rupiah. Secara simultan, stabilitas nilai tukar rupiah dipengaruhi oleh variabel pandemi (kasus, kematian, pemulihan dan kebijakan manajemen pandemi, jumlah uang beredar (M1, M2), operasi pasar (konvensional dan syariah), suku bunga acuan (BIrate), tingkat inflasi, cadangan devisa, indeks saham keuangan. Kebijakan penanganan pandemi apapun namanya cenderung melemahkan posisi nilai tukar rupiah, nilai tukar rupiah. terhadap rupiah, sedangkan pembentukan satgas berdampak lebih ringan dalam menekan rupiah dibandingkan dengan kebijakan lainnya.(Junaedi \& Arsyad, 2021).

Pandemi Covid-10 yang berkepanjangan berdampak signifikan terhadap dinamika pasar modal dunia, termasuk Indonesia. Pergerakan indeks saham gabungan (IHSG) di Bursa Efek Jakarta dipengaruhi oleh kondisi internal dan eksternal. Secara internal, kondisi pandemi Covid-19 dan kebijakan social distancing (WFH dan PSBB) di dalam negeri telah mempengaruhi dinamika pasar saham (ditunjukkan dengan pergerakan indeks IHSG di BEJ). Dari sisi eksternal, pandemi Covid-19 di China dan Spanyol turut memengaruhi dinamika pasar saham di Indonesia (indeks IHSG). Begitu pula dengan dinamika pasar saham di Hongkong (Hangseng), London (FTSE100) dan News York (NASDAQ). Pandemi virus Corona di Indonesia, China, dinamika pasar saham Nasdaq di New York, dan kebijakan social dintancing (WFH dan PSBB) berdampak negatif terhadap pergerakan indeks saham IHSG. Sedangkan pandemi di Spanyol, dinamika pasar saham di Hongkong (Hangseng) dan 


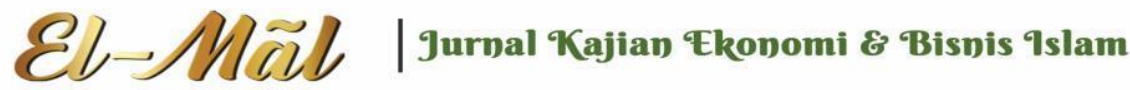

\section{Vol 3 No 2 (2020) 144-155 P-ISSN 2620-295 E-ISSN 2747-0490 DOI: 1047467/elmal.v3i1.507}

London (FTSE100) justru berdampak positif terhadap kondisi pasar saham di Indonesia (Junaedi \& Salistia, 2020).

Pandemi yang berlangsung lebih dari 18 bulan telah nyata berdampak bagi perekonomian masyarakat Kabupaten Bogor (Junaedi et al, 2021), khususnya dalam lingkup keluarga civitas akademika IAI Nasional Laa Roiba Bogor. Sebelum pandemic, memang ada masyarakat yang merasakan penurunan penghasillan. Tetapi mayoritas $(60 \%)$ masih mengaku pendapatan relatif stabil. Setelah pandemic, mayoritas masyarakat (75\%) mengalami penurunan pendapatan. Pandemi telah menyebabkan sebagian besar masyarakat mengalami penurunan pendapatan bulanan antara 5-20\%. Pandemi membuat masyarakat berupaya mencari tambahan penghasilan lewat usaha kuliner, kerja paruh waktu, kerja serabutan, dan menyediakan jasa konsultasi. Pandemi juga menggeser pola belanja masyarakat dari pasar tradisional ke pasar online. Makanan siap saji dan kebutuhan pokok menjadi target belanja online masyarakat Bogor. Di tengah kesulitan, muncul harapan bahwa pandemi dapat segera berakhir dan keadaan Kembali normal. (Junaedi et al, 2021)

\section{DAFTAR PUSTAKA}

Alfira, N., Fasa, M., \& Suharto, S. (2021). Pengaruh Covid-19 terhadap Indeks Harga Saham Gabungan (IHSG) dan Nilai Tukar Rupiah. Al-Kharaj : Jurnal Ekonomi, Keuangan \& Bisnis Syariah, 3(2), 313323. https://doi.org/10.47467/alkharaj.v3i2.356

Alhusain, A.S. (2021). Bank Syariah Indonesia: Tantangan Dan Strategi Dalam Mendorong Perekonomian Nasional. Info Singkat: Kajian Singkat Terhadap Isu Aktual dan Strategis Bidang Ekonomi Dan Kebijakan Publik, XIII(03).

Diakses dari: https://berkas.dpr.go.id/puslit/files/info_singkat/Info\%20Singkat-XIII-3-IP3DI-Februari-2021-197.pdf.

Amirillah, A. (2014). Efesiensi Perbankan Syariah di Indonesia. JEJAK Journal of Economics and Policy, 7 (2): 141-150. doi: 10.15294jejak.v7i1.3596.

Arifin, Z. (2002). Dasar-Dasar Manajemen Bank Syariah, cetakan pertama. Jakarta: Alfabeta.

Arifqi, M., \& Junaedi, D. (2021). Pemulihan Perekonomian Indonesia Melalui Digitalisasi UMKM Berbasis Syariah di Masa Pandemi Covid-19. Al-Kharaj : Jurnal Ekonomi, Keuangan \& Bisnis Syariah, 3(2), 192-205. https://doi.org/10.47467/alkharaj.v3i2.311

Ensiklopedia Bank syariah. (n.d.).

Junaedi, D., \& Salistia, F. (2020). Dampak Pandemi Covid-19 terhadap Pasar Modal di Indonesia. Al-Kharaj : Jurnal Ekonomi, Keuangan \& Bisnis Syariah, 2(2), 109-131. https://doi.org/$\underline{10.47467 / a l k h a r a j . v 2 i 2.112}$ 


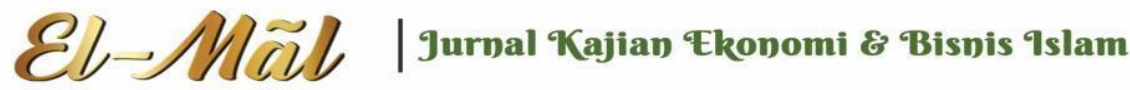

\section{Vol 3 No 2 (2020) 144-155 P-ISSN 2620-295 E-ISSN 2747-0490 DOI: 1047467/elmal.v3i1.507}

Junaedi, D., \& Salistia, F. 2020. Dampak Pendemi Covid-19 terhadap Pertumbuhan Ekonomi Negaranegara Terdampak. Paper Prosiding Simponium Nasional Keuangan Negara (SNKN) 2020. Jakarta: BPPK Kementerian Keuangan RI.

Junaedi, D., \& Salistia, F. (2020). Dampak Kawasan dan Status Negara Terhadap Pertumbuhan Ekonomi Negara-Negara Terdampak Covid-19. Al-Kharaj : Jurnal Ekonomi, Keuangan \& Bisnis Syariah, 3(1), 37-56. https://doi.org/10.47467/alkharaj.v3i2.187

Junaedi, D., Arsyad, M., Norman, E., Romli, M., \& Salistia, F. (2020). Dampak Pandemi Covid-19 terhadap Stabilitas Moneter Indonesia. Al-Kharaj : Jurnal Ekonomi, Keuangan \& Bisnis Syariah, 3(1), 17-36. https://doi.org/10.47467/alkharaj.v3i1.149

Junaedi, D., Arsyad, M., \& Aurijah, S. (2020). Optimalidasi Investasi Dana Haji Era Pandemi Covid19. Al-Kharaj : Jurnal Ekonomi, Keuangan \& Bisnis Syariah, 3(1), 1-16. https://doi.org/10.47467/alkharaj.v3i1.150

Junaedi, D., Arsyad, M., Salistia, F., \& Romli, M. (2021). Dampak Covid-19 terhadap Perekonomian Masyarakat Bogor. Reslaj : Religion Education Social Laa Roiba Journal, 3(2), 206-226. https://doi.org/10.47467/reslaj.v3i2.283

Hutauruk, D. M. (2020, 17 Maret). Bank Syariah Kaji Opsi Pemangkasan Target Pembiayaan Akibat Wabah Virus Corona. KONTAN.CO.ID. https://keuangan.kontan.co.id/news/bank-syariah-kajiopsi-pemangkasan-target-pembiayaan-akibat-wabah-virus-corona?page=all

Karsinah, K., \& Cahya, A.R.K. (2014). Kinerja Bank Umum Syariah Di Indonesia Tahun 2010-2012. JEJAK: Jurnal Ekonomi Dan Kebijakan, 7(2), 158-172.

Laucereno, S.F., (2020, 24 Maret). Gubernur BI: Kami Minta Perbankan Segera Turunkan Bunga Kredit. DetikCom. Diakses dari https://finance.detik.com/moneter/d-4951911/gubernur-bikami-minta-perbankan-segera-turunkan-bunga-kredit.

McAleer, M. (2020). Prevention is better than the cure: Risk management of COVID-19. J. Risk Financial Manag. 13(3), 46. https://doi.org/10.3390/jrfm13030046.

Misra, B. M., \& Dhal, S. (2010). Pro-cyclical management of banks' non-performing loans by the Indian Public Sector Banks. BIS Asian Research Papers, 16, 1-23.

Otoritas Jasa Keuangan. (2017). Perbankan Syariah dan Kelembagaannya. Diakses dari https://www.ojk.go.id/id/kanal/syariah/tentang-syariah/Pages/PBS-dan-Kelembagaan.aspx.

Otoritas Jasa Keuangan. (2020a). Pertumbuhan PDB (y-on-y) 2020.

Otoritas Jasa Keuangan. (2020b). Stimulus Perekonomian Nasional Sebagai Kebijakan Countercyclical Dampak Penyebaran Corona Virus Disease 2019. JDIH BPK RI. Data Base Peraturan. https://peraturan.bpk.go.id/Home/Details/135560/peraturan-ojk-no11pojk032020-tahun-2020.

Perwataatmadja, K. (1992). Peluang dan Strategi Operasional Bank Muamalah. Makalah Seminar Sehari Kiat Bisnis Dari Sudut Pandang Islam, di Garden Palace Hotel Surabaya, 12 September 1992.

Phan L.T., Nguyen T.V., Luong Q.C., Nguyen T.V., Nguyen H.T., \& Le, H.Q. (2020). Importation and 


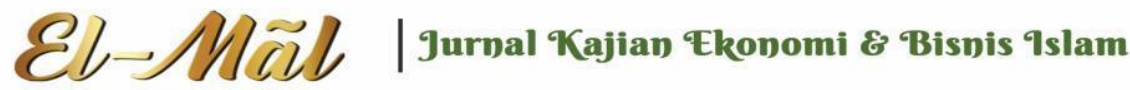

\section{Vol 3 No 2 (2020) 144-155 P-ISSN 2620-295 E-ISSN 2747-0490 DOI: 1047467/elmal.v3i1.507}

Human-to-Human Transmission of a Novel Coronavirus in Vietnam. $N$ Engl J Med. 2020;382:872-874. https://10.1056/NEJMc2001272.

Undang-Undang Nomor 2 Tahun 2020 Tentang Penetapan Peraturan Pemerintah Pengganti Undang-Undang Nomor 1 Tahun 2020 tentang Kebijakan Keuangan Negara dan Stabilitas Sistem Keuangan untuk Penanganan Pandemi Corona Virus Disease 2019 (Covid-19) dan/atau Dalam Rangka Menghadapi Ancaman yang Membahayakan Perekonomian Nasional dan/atau Stabilitas Sistem Keuangan Menjadi Undang-Undang.

Statistik Perbankan Syariah. (2020). https://www.ojk.go.id/id/kanal/syariah/data-danstatistik/statistik-perbankan-syariah/Documents/Pages/Statistik-Perbankan-Syariah--Januari-2020/SPS Januari 2020.pdf.

Sumarni, Y. (2020). Manajemen Ekonomi Islam dalam Menangani Pandemi Coronavirus Disease (COVID-19) di Indonesia. Jurnal BAABU AL-ILMI: Ekonomi Dan Perbankan Syariah, 5(1), 117126.

Syukra, R. (2020, 1 Mei). Pasca Covid-19, Laju Pertumbuhan Ekonomi Indonesia Tak Langsung Pulih. Investor Daily. Diakses dari: https://investor.id/business/pasca-covid19-lajupertumbuhan-ekonomi-indonesia-tak-langsung-100-pulih.

Thariq, B.A. \& Goniewicz, T. (2020). SARS-CoV-2 Load in Upper Respiratory Specimens of Infected Patients. The New England Journal of Medicine.

Warjiyo, P. (2004). Mekanisme Transmisi Kebijakan Moneter di Indonesia. Pusat Pendidikan dan Studi Kebanksentralan BI, volume 11.

Yamin, M. (2007). Desain Pembelajaran Berbasis Tingkat Satuan Pendidikan. Jakarta: Gaung Persada Press. 